\title{
ADJUSTING THE MORTGAGOR'S OBLIGATION TO ECONOMIC CYCLES
}

\author{
David L. WICRENS*
}

The alternate occurrence of prosperity and depression has been the principal obstacle to the successful functioning of real estate mortgage finance. This type of credit usually involves large individual commitments in comparison with the assets of borrowers, and in the aggregate is the largest segment in the credit structure of the nation. Maladjustments in this credit structure, in view of its paramount importance both to borrowers and to lenders, have all too frequently ended in grave financial difficulty and frustration of the original purposes of at least one of the parties to the contract. As a rule, mortgages carry fixed and uniform payments which must be met promptly over a period of years, regardless of the income of the borrower or his changing ability to pay. Incomes from whatever source, whether from farming or industrial activities, have typically fluctuated widely in the United States.

The requirements for adjustment of the mortgagor's obligation to fluctuating economic conditions extend to a consideration of the actual variations that occur in the capacity of the mortgagor to pay. It is characteristic of business depressions that there are declines in demand for goods and services, falling prices, growing unemployment, lowered wages, reductions in rents, and contraction of credit. For example, cash farm income declined from ro.5 billion dollars in 1929 to 4.3 billion dollars in 1932. Incomes of persons receiving wages and salaries, according to the estimates of the United States Bureau of Foreign and Domestic Commerce, declined from $5^{\mathrm{r}} .3$ billion dollars in 1929 to 29.3 billion dollars in $1933 .{ }^{2}$ Incomes of individual families also declined precipitously. In 1933, owner-occupant families in 52 cities, covered by the Financial Survey of Urban Housing, had incomes $36.4 \%$ smaller than in $1929 .^{3}$

- A.B., I913, Morningside College; A.M., 1925, University of Chicago; LL.D. (Hon.), 1938, Morningside College. Member, research staff, National Bureau of Economic Research, directing study of real estate financing and economic stability. Special consultant on finance and credit, Farm Security Administration; U. S. Department of Agriculture. Project director, Financial Survey of Urban Housing, Bureau of Foreign and Domestic Commerce, U. S. Department of Commerce, 1933-1935; Economist, Division of Agricultural Finance, Bureau of Agricultural Economics, I926-r935; farmer. Author of numerous works and articles on agricultural and urban real estate financing problems.

${ }^{1}$ U. S. Bureau Agr. Econ., Agricultural Statistics, 1937, p. 337, table 443.

${ }^{2}$ Nathan and Cone, Monthly Income Payments in the United States, 1929-1938, U. S. DEPT. of CoMMierce, Sunvey op Current Business, Feb. r938.

'Unpublished tabulations by the National Bureau of Economic Research. 
First of all, it is necessary to recognize that fluctuations of this kind are the rule, not the exception. In undertaking an adjustment of mortgagors' obligations to such basic economic changes it is first necessary to alter the basic tenet of most mortgage contracts, that is, the provision for fixed payments in the face of changing levels of income. In the past, during periods of depression, the customary uniform payments on mortgages necessary to keep loans in good standing have taken an increasing proportion of the mortgagor's available funds, as incomes declined. This is especially notable in the case of farm mortgages and mortgages on city homes. The result has been that other demands on income were denied part or all of their usual claims. The amount spent for clothing or furniture or education or food was definitely reduced. Notwithstanding valiant attempts at economy along other lines, however, the result in periods of severe depression, such as the period I929-1933, has been ultimate default on many loans and eventual loss of properties. Delinquency in farm loans may be illustrated by the fact that on December $3 x, 1932,45 \%$ of the loans of the Federal Land Bank were in default. ${ }^{4}$ Farms changing hands because of forced sales and related defaults aggregated 54.I per 2,000 in the year ending March $1933^{\circ}$ Non-farm real estate foreclosures in I933 are estimated at 252,000 for the country as a whole, or 13.3 per 1,000 non-farm dwellings. ${ }^{B}$ In 52 representative cities covered by the Financial Survey of Urban Housing, $4 \mathrm{r} .9 \%$ of the mortgages in the owneroccupied group were in default. ${ }^{7}$ It is this problem of making payments adjustable to current income-not for an individual family, but for large groups of borrowersthat must be met. It is probably basic to a sustained expansion of construction and real estate activity.

The general mortgage practice in the past has ignored this inherent conflict between fluctuating income and fixed obligations, or has undertaken to proceed in spite of it. Mortgage contracts have continued to be made regardless of the probability of future changes in business conditions which affect ability to make payment. Attempts to guard against the risk of loss have been limited mainly to controlling certain leading features of the contract, such as the restriction of the mortgage to a moderate percentage of the value of the property, limiting the term of the loan to a short period of years, and the specification of an interest rate high enough to allow for possible loss. While these measures reduce the hazard involved in extension of credit, they also limit the service which that type of financing renders. Thus they seek to solve the problem by avoiding it. In recent years there has been a pronounced tendency to increase the ratio of the value of the loan to the aggregate value of the property and to lengthen the period of years within which the debt must be paid. Although amortization provisions usually have accompanied the extension of the length of the loan term, experience has shown that amortization does not constitute adequate protection against the vicissitudes of changing business conditions.

\footnotetext{
- Farm CRedit QunRterly, December 1937.

¿ U. S. Bureau Agr. Econ., Agricultural Statistics, 1936, p. 351, table 457.

- F. H. L. B. B., Non-Farm Real Estate Foreclosures, December 1937 (mimeographed).

T Unpublished summary tabulations by the National Bureau of Economic Rescarch.
} 
The net result of these reccnt morrgage policies has been the appearance of larger loans, of commitments for longer periods of time, accompanied by an increase in certain of the hazards involved in the extension of this type of credit.

Recently, also, there has been an increased use of guarantee or insurance of mortgages, securing the mortgagee against loss of the principal of the loan, and, in general, providing loans of a higher ratio to value of the property with longer terms and provision for amortization. These measures do not provide means of adjusting the borrower's obligation. The guarantee is, rather, a method of assuming a part of the lender's risk. The assumption back of the insurance or guarantee method is that the guarantor will be able to withstand the financial strain of a severe depression even though called upon to provide a large amount of cash or other liquid assets to meet the guarantec. The substitution of guarantees by governmental agencies for guarantees by private institutions still leaves the basic problem of the debtor's burden unsolved. Although the guaranteeing capacity is greatly increased by this change, the huge potential volume of real estate credits, together with other very large guarantees which the government now assumes, may yet place a limit upon the ultimate practicability of such guarantees.

In the aftermath of the '20's guarantees-usually of mortgage bonds-almost without exception ended in the bankruptcy of the guarantor and the disappointment of investors who had relied upon the guarantee for the safety of their mortgage investments. As the business depression which began in 1929 took on large proportions it soon became evident that the limited assets of the guarantors were totally inadequate to make good the tremendous volume of claims represented by the so-called guaranteed mortgages. The unrealistic conception of the resources required for guarantee of mortgages on a large scale in this case was partly due to the failure to understand the amount of shrinkage which could occur in the property values which constituted the security for the mortgages.

The National Bureau of Economic Research has recently shown in an unpublished study that value of residential real estate in 1930 was over 122 billion dollars and that four years later this volume had declined by no less than one-third. Home properties represented about one-half of the total of all types of real estate at the time. Assuming that in 1930 approximately half of this property value was encumbered with debts, that that debt was represented by guaranteed mortgages amounting to 80 or $90 \%$ of the value of the properties-aggregating, say 48 to 54 billion dollars-it is reasonable to believe that the collection of these guarantees on loans aggregating such a large volume, incident to a decline of one-third in real estate values, would have offered definite fiscal problems to the guarantor. It is universally recognized that a community, as a collection of individuals, cannot guarantee all of the mortgages within its area. Since real estate constitutes more than half of the national wealth and since current living and operating costs will always be given preference in their claims on current income, it appears to be impracticable to 
provide a universal guarantee of real estate values by means of guaranteeing mortgages, particularly when they represent a high ratio of the value of the property.

The inescapable alternative for providing protection to the mortgagor's obligation would seem to be the provision of such terms and conditions within the mortgage instrument itself as will assure the continued validity of the mortgage by making its terms feasible of performance.

Any contract must, of course, be definite in its terms. It must also be clear that the total amount of the debt will be due and payable within a specified period of years as in the usual loan contract. The principal departure involved in a loan designed to protect the mortgagor would be that the amount payable in any single year or period of time would be allowed to vary with the income of large groups of individuals received during that period, rising in periods of large income and declining in times of reduced income. Subject to such safeguards as might be necessary to continue the administrative machinery and to provide for meeting the current obligations of the supplier of funds, this general method of adjusting payment to ability offers the best prospect for a solution of this problem. Possible plans for accomplishing this purpose are discussed at the end of this article.

The problem of adjusting the mortgagor's obligation must always be closely related to the legal provisions involved in financing. Mortgage experience to date, however, has shown that too much reliance has been placed on the effectiveness of legal contractual provisions and insufficient attention has been given to economic realities.

Granted that credit must always have a legal framework in order to give confidence in its pledges and to insure enforcement of its terms, it may be assumed that if adjustment of the terms of the mortgagor's obligation to cyclical economic problems is to be made satisfactory legal provisions must be written in the light of economic eventualities. If mortgage financing is to be carried on without accentuating depressions and without bringing hardship and bankruptcy during periods of decline in income, arrangement must be made for adjusting yearly payments to accord with yearly income.

One compelling reason for flexible mortgage payments is that, without express provision for such payments, payments actually made are adjusted downward in practice, after a period of time, because of the limitation of individuals' means. This takes place, after delay and hardship, through defaults, delinquencies, and foreclosures. The total of actual payments on mortgages during depression is always greatly reduced below the contractual requirements, so that creditors, in fact, receive less than they expect or their contract calls for, usually after a period of considerable sacrifice on the part of the debtor who attempts to fulfill his obligation. Foreclosure, in a major depression, offers little relief to creditors, because as a rule the real estate market is glutted and property cannot be disposed of at any price.

The fact that mortgage contracts represent voluntary agreements between borrowers and lenders does not suffice to assure that such contracts will adequately pro- 
tect either the borrower or the public from the ill consequences of their terms. Most borrowers seeking a mortgage loan are intent upon the immediate problem of arranging financing to accomplish a specific purpose. It is probably true that only a small minority of borrowers visualize the possible contingencies that may arise through economic changes during the term of the loan.

Moreover, as a general rule the type of mortgage contracts available in the community take their pattern from the customary practice of the area, developed over a long period of years, and which may or may not be adapted to the economic situation. of the community either with respect to rates of interest or other terms of the loan. Aside from the amortized loan, which has developed important proportions in recent years, the mortgage loan has had the general character of a commercial short-term loan, with little recognition, as far as the payment system is concerned, of the difference in the nature of a mortgage loan and of a commercial loan.

Even the amortized loan adheres to the practice of requiring uniform payments for each year regardless of changes in the earning power of the asset which forms this security. The result of this practice was seen in the recent depression when, in 1932, the amortized farm loans of the Federal Land Banks and the Joint Stock Land Banks had the same percentage in arrears as was reported for the aggregate of all types of farm loans in the country as a whole.

The social importance of protecting the mortgagor's obligations from cyclical changes extends far beyond the interest of the individual borrower. As borrowers in any considerable number fail to meet their obligations, the economic effect is registered upon the community as a whole. The recent depression illustrated once more the fact that default of mortgage loans not only embarrasses the mortgagor by disrupting his financial arrangement but also extends its effect to the entire community, through the embarrassment or failure of financial institutions, the curtailment of income on which individuals and institutions are dependent, and through the wiping out of assets on which investors relied. In recent years the community has assumed an increasing part of the burden resulting from widespread mortgage defaults by providing relief for stranded individuals left without resources. Moreover, public resources have been drawn upon for taking over defaulted mortgage contracts after their specified terms proved impossible of fulfillment. If in these cases a part of the excess income received during prosperity had been applied on the interest and principal of the debt, the community would not have had so much of this salvage work to perform.

This consideration of the economic ills induced by the inflexible payment mortgage has so far emphasized primarily the undesirable consequences which arise in periods of depression, when lowered incomes and reduced economic activity result in the extensive loss of property. This, however, is only one side of the picture. It is necessary also to examine the financial processes as they operate during periods of prosperity. When increased profits and savings in excess of the amounts required for current expenses are gradually accumulated and used to make payments on real 
estate, prices of property are bid up. Only a small part of the real estate transactions in a period of rising values are made with a complete cash payment. The great majority of purchases are made with a limited down payment and a much larger amount of credit carried against the property, either as a mortgage to the vendor, or in the form of a loan, or both.

It is to be emphasized that this increase in real estate activity, which accompanies all sustained periods of prosperity and which in the United States has frequently developed into booms of alarming proportion, is due to the investment in real estate of the excess savings not required for current expenses. The average American with a surplus of funds on his hands is most likely to turn to real estate, the type of asset most universally available and the one with which investors the country over are most familiar.

A system of payments which required the application of excess savings toward the reduction of the principal of the debt in good times would automatically limit this flow of surplus funds into real estate investments. The expenditure of income is most likely to follow a pattern laid down in advance either by the usual family expenditures or by a pre-arranged system of scheduled or enforced savings.

Experience with the payment of insurance premiums and installment purchases has demonstrated that these methods of enforced saving establish payment habits which are generally adhered to as long as it is possible to do so. A payment system which would require the automatic sharing with the creditor of the earnings of a property in good times, or which would require that payments on the debt, both as to principal and interest, be made proportionate to income from the property, would automatically act as a restraint upon incipient real estate booms. The withholding from the real estate market of these excess funds would have a tendency to retard undue advances in the price of real property. Values would not rise so high on the up-swing, and the amounts of indebtedness incurred incident to purchase of real estate would be held to more reasonable proportions. This restraint on the rise of property values is one of the most important respects in which the borrower's obligation needs protection. The ultimate safety of any loan extending over a long period of years will be imperiled if it is initiated in a period of excessive values. This is amply illustrated by the experience with the farm loans made during the years 1918-1920. The value of a property is only the capitalization of its future income. If the future income has been erroneously anticipated, the most that any system of payment can be expected to accomplish as the years go by is the equalization of the mortgage burden as it varies with the income of those years. It cannot compensate for the absence of income falsely implied in the value at which the purchase was made.

For these reasons a system of flexible payments is needed to protect the mortgagor's obligations and the interest of the community during periods of prosperity as well as in depression. Various devices may be used to vary mortgage payments so that they accord with the stream of income which constitutes the means for payment. 
The simplest form of financing is direct and complete ownership of the real estate. This may be said to be completed financing, in which the buyer himself derives the income from the property purchased. This is often used in individual ownership of houses and farms or other real estate, but is not, strictly speaking, a loan arrangement.

Another system is stock ownership, in which a group of investors pay in the full value of the property and share its return in proportion to the amount of their stock. This device, which has been so extensively employed in the corporate field, might well be more generally used with real estate. By this means the financing party is the stock holder, who would advance the necessary financing by purchasing an interest in the property.

Cumulative preferred stock might be used to accomplish the same purpose. Under this plan the rate of return for the loan period as a whole could be fixed but the amount payable in any given year would depend upon the available earnings for that year. Deficiencies would accumulate and be paid in years of excess earnings. A variation of this plan could provide that in certain periods of years the returns must be made to equal the coupon rate times the number of years in the period. This would in effect be a combination of the fixed percent mortgage with flexibility to the extent that the amount payable in a given year would vary with returns, while the total balance remaining would be required at the end of the period with the penalty for non-payment consisting of forfeiture of the security.

A further variation involves a combination of a fixed rate for one part of the loan and flexible rate of financing for the remainder. A first mortgage for a very conservative percentage of the value of the property could be made to bear a fixed rate of return each year. The balance of the financing could be made to vary with the income available.

There is, however, the problem of the small individual property, to which these situations and conditions are not applicable. In any flexible payment system for such properties, in addition to a clear definition of the terms of the loan, it is also necessary to provide an accurate, unbiased and well-publicized yardstick by which changing ability to pay and varying mortgage payments can be measured. It is obviously impossible to adjust each and every mortgage to the ability of the individual borrower to pay, but most severe fluctuations which it is economically important to take into account usually affect large groups of borrowers simultaneously. Thus, for farm mortgages, annual payments of interest and principal could vary with the current prices and yields of one or two major crops in the area during each season, as regularly published by the United States Department of Agriculture, worked out in accordance with a pre-arranged schedule. Thus, the payments would be figured in - what would amount to the current money value of a given number of hogs or bushels of wheat or corn, adjusted upward or downward according to variations of the crop yield from a long-term average for the area. In years of high prices, money payments would exceed the usual amount, and in years of crop failure or low prices, 
payments would be smaller, without putting the mortgage into default. Such a credit arrangement is similar to that of buying or renting on a crop-sharing plan, a system in operation for years on thousands of farms throughout the country. A detailed schedule of varying payments for principal crops and leading agricultural areas is available, but because of limitations of space is not given here.

For city properties, and in particular for residential properties which constitute the bulk of urban real estate, the problem is more difficult, since the incomes of home owners are derived from so many different sources. A yardstick based upon aggregate payrolls in basic industries, as published by the United States Bureau of Labor Statistics, might provide a possible basis for judging ability of city dwellers to pay.

Loans varying their annual payments in such a manner as this should be practicable, if carefully worked out, and should safeguard both-borrowers and lenders against potential losses by recognizing the fact that income, unlike the traditional fixed mortgage payments, in fact varies widely. 